\title{
Effect of Cadmium Chloride on the Development of Chrysomya Megacephala (Diptera:Calliphoridae) and its Importance to Postmortem Interval Estimate
}

\author{
Singh D and Bhupinderjit Kaur Heer* \\ Department of Zoology and Environmental Sciences, Punjabi University, India
}

Submission: June 19, 2017; Published: July 10, 2017

*Corresponding author: Bhupinderjit Kaur Heer, Department of Zoology and Environmental Sciences, Punjabi University, Patiala, India, Email: bhupinderjitkaur.heer@gmail.com

\begin{abstract}
Cadmium chloride is one of the highly toxic compounds among the heavy metals. It exerts a negative impact on the living organisms and accumulates in food chain and could lead to some serious problems, such as high rate of mortality, lower longevity, decreased fecundity and lower hatching ability of many insects and other arthropods. The present work dealt with the evaluation of cadmium chloride because there is lack of published entomotoxicological reports for cadmium chloride have evaluated their effect on the growth and development of this forensically important fly blow fly species, Chrysomya megacephala (Diptera: Calliphoridae). Larvae of Chrysomya megacephala (Diptera: Calliphoridae) reared on rat tissues that were previously exposed to Cadmium chloride ( $\mathrm{CdCl} 2)$ in different concentrations: Half lethal (3.25mg/kg bw), Lethal $(6.5 \mathrm{mg} / \mathrm{kg} \mathrm{bw})$ and Twice Lethal $(13 \mathrm{mg} / \mathrm{kg} \mathrm{bw})$ by intraperitoneal injection (i.p.). Development rate, larval body length, width, weight, pupal and adult weight and mortality were the observed parameters. Results demonstrated that the development rate of larvae between treated group and control group varied significantly. Development took longer time in the presence of high Cadmium concentration compared to control. Mortality results indicated greater mortality among the larvae with increased cadmium concentration as compared to control. It can be concluded that Cadmium chloride has negative effect on all the life stages of Chrysomya megacephala. Since cadmium chloride alters the rate of development in Chrysomya megacephala. There are chances of miscalculation of PMI if the presence of cadmium chloride is not taken into consideration. For example there could be wrong estimation of PMI by up to 18-86 hours if age of larvae is determined on the basis of its length ignoring the effect of cadmium chloride.
\end{abstract}

Keywords: Cadmium chloride; Chrysomya megacephala; Development rate; Postmortem interval

\section{Introduction}

With industrialization, the use of heavy metals has increased tremendously during the last few decades. Heavy metals have high toxicity and are no biodegradable. They can be accumulated by the organisms and affect the development and physiological state of the individual. Different studies have been conducted on the effect of heavy metals on insects [1-8] They have been reported to have resulted in alterations of respiratory [9] and metabolic processes [7,10-16].

Cadmium chloride is one of the highly toxic compounds among the heavy metals. It exerts a negative impact on the living organisms and accumulates in food chain and could lead to some serious problems, such as high rate of mortality, lower longevity, decreased fecundity and lower hatching ability of many insects and other arthropods [3,5,17-20]. AL- Misned [21] studied the effect of cadmium on the development of Chrysomya I[22]. Studied the accumulation of cadmium and its effects on growth, development and hemolymph biochemical compositions in Boettcherisca peregrina larvae (Diptera: Sarcophagidae) and results demonstrated that cadmium had negative effects resulting in significant reduction both in larval body weight and length [23]. Studied the effect of cadmium on the Gypsy moth Lymantria dispar $\mathrm{L}$ and concluded that cadmium had no affect on the larval duration but shortened the pupal duration and reduced the pupal mass. The development of insects is dependent upon the ambient temperature [15,24-27]. Similarly the quantity and quality of food also plays a significant role in the rate of growth [28-37]. Several chemicals present in the food also interfere with the normal development of blow flies [38-49]. 
Chrysomya megacephala is a forensically important blow fly distributed in many parts of the world and available throughout the year in northwestern part of India [50-52]. Larvae of this species have been reported in association with human corpses in several cases [53-59]. The effects of cadmium chloride on the development rate, length, width and weight of larvae, pupal weight, adult weight and mortality of blow fly Chrysomya megacephala have been investigated in the present study.

\section{Materials and Methods}

\section{Insect rearing and experimental group}

Stock colony was populated from the wild type specimens Chrysomya megacephala collected with the help of sweeping net from Punjabi University Campus by using goat skeletal meat as bait. The culture was maintained out of phase such that each generation comprised a number of emergences separated over time to provide a mix of different aged gravid females. Generations were conserved in a way that no intergenerational mating occurred, except when newly trapped wild type individuals were added to the culture. This stock colony was repopulated, when required.

\section{Animal Ethical Committee permission}

Institutional Animal Ethical Committee (vide letter no. 107/99/CPCSEA-2012-12).

\section{Cadmium chloride treatment}

Female Sprague-Dawley laboratory rats (100-110 g) were used for experiments that were previously exposed to cadmium chloride $\left(\mathrm{CdCl}_{2}\right)$ in different concentrations: Half lethal $(3.25 \mathrm{mg} /$ $\mathrm{kg} \mathrm{bw}$ ), Lethal (6.5 mg/ kg bw) and Twice Lethal (13 mg/kg bw) by intraperitoneal injection (i.p.). Newly hatched larvae (250300 ) were obtained from these laboratory breed colonies and allowed to feed upon the rat carcasses CD1 (Half Lethal), CD2 (Lethal) and CD3 (Twice Lethal). Controls were also maintained to compare with the treated group in order to study the effect of cadmium chloride only leaving the other factors unaltered (food, temperature humidity etc.). Two replicates were done and the results combined for analysis. Time of hatching was noted and subsequently development time was estimated for each larval instars $\left(1^{\text {st }}, 2^{\text {nd }}\right.$ and $\left.3^{\text {rd }}\right)$, post feeding larvae, pupa and time of emergence of adults. 15 larvae were randomly collected at 8 hour intervals. 5 larvae were used to determine growth based on weight increase and 10 larvae were measured to determine development based on increase in total length and width. Minimum and Maximum temperature and humidity were noted daily by using Electronic Thermo hygrometer (Maximum daily temp. $24.5 \pm 2{ }^{\circ} \mathrm{C}$, Minimum daily temp $22.5 \pm 2{ }^{\circ} \mathrm{C}$, Relative Humidity 68\% - 72\% and Photoperiod LD 10: 14) .

\section{Data analysis}

Data were analyzed using Arithmetic Mean, Standard deviation, Analysis of Variance (ANOVA) and Chi square test. Graphs and tables were prepared using Microsoft Excel 2007.

\section{Results and Discussion}

\section{Larval development}

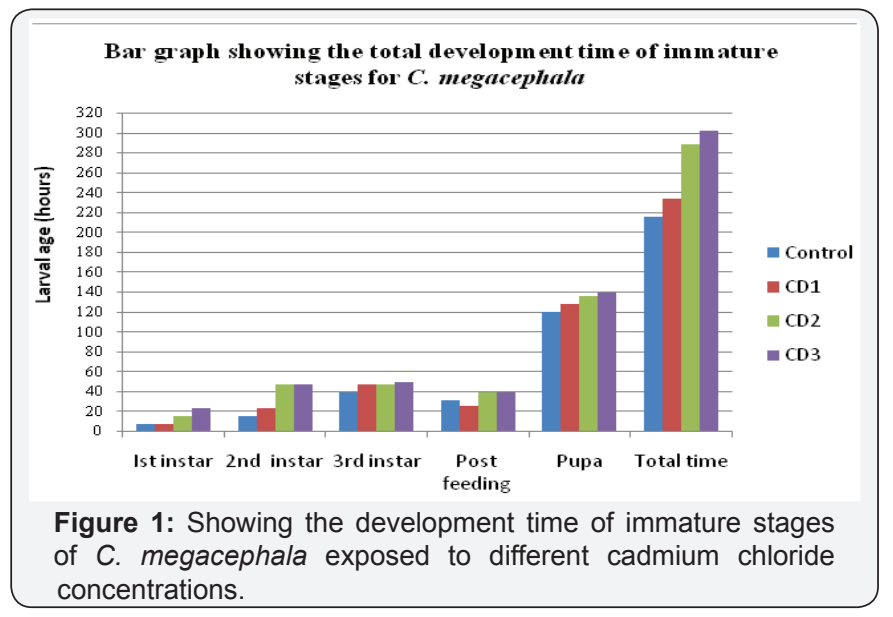

Development time from egg to adult was significantly different for C. megacephala reared on tissues with different dosages of cadmium chloride (Figure 1). There were highly significant differences between the mean larval development times among the different concentrations of cadmium chloride for first instar $(\mathrm{F}=2,051.74, \mathrm{P}=0.000)$, second in $\operatorname{star}(\mathrm{F}=4,439.251, \mathrm{P}=0.000)$, third in star $(\mathrm{F}=6,924.611, \mathrm{P}=0.000)$, post feeding stage $(\mathrm{F}=10,224.815, \mathrm{P}=0.000)$, pupa $(\mathrm{F}=5,907.292, \mathrm{P}=0.000)$ and total development $(\mathrm{F}=58,698.74, \mathrm{P}=0.000)$. It can be concluded that the presence of the cadmium chloride had a significant impact on larval growth and also delayed the pupation by larvae [22] Showed that there is no effect of cadmium on the development of Drosophila melanogaster but adults died without egg lying [59]. Studied the effect of cadmium on Chironomus riparius and that caused the prolongation in the development of first and second instar stage $[3,18]$. Concluded that duration of nymphal stages of Aiolopus thalasinus was prolonged when exposed to cadmium up to $100 \mathrm{ppm}$ in soil. Al- Misned [21] showed that development time of larvae of Chrysomya albiceps was extended with increasing cadmium concentration.

\section{Larval length and width}

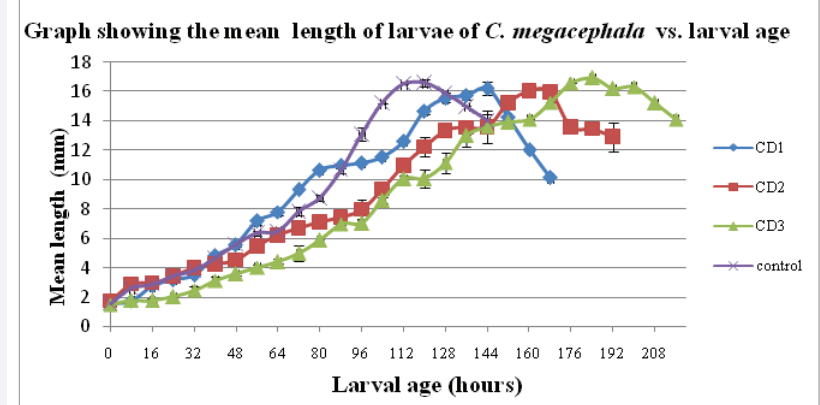

Figure 2: Showing the mean length of immature stages of C. megacephala exposed to different cadmium chloride concentrations.

Length has been one of the most frequently used parameters for successfully estimating larval age [57-58]. It is measured 
between the head and the tip of the eighth abdominal segment [30]. The development curves created from the larval length are shown in (Figure 2). There were significant differences in the lengths of the larvae feeding upon the different doses of cadmium chloride and the time required to reach the maximum length $(F=6,713.356 ; p=0.000)$. The maximum lengths for the larvae feeding upon CD1 (16.2 $\pm 0.05 \mathrm{~mm})$, CD2 (16.05 $\pm 1.12 \mathrm{~mm})$, CD3 $(16.09 \pm 0.07 \mathrm{~mm})$ and control $(16.59 \pm 0.09 \mathrm{~mm})$ were recorded at 144 hours, 160 hours, 184 hours and 120 hours respectively. This shows that larvae took more time to attain the maximum length as the concentration of the cadmium chloride increased.

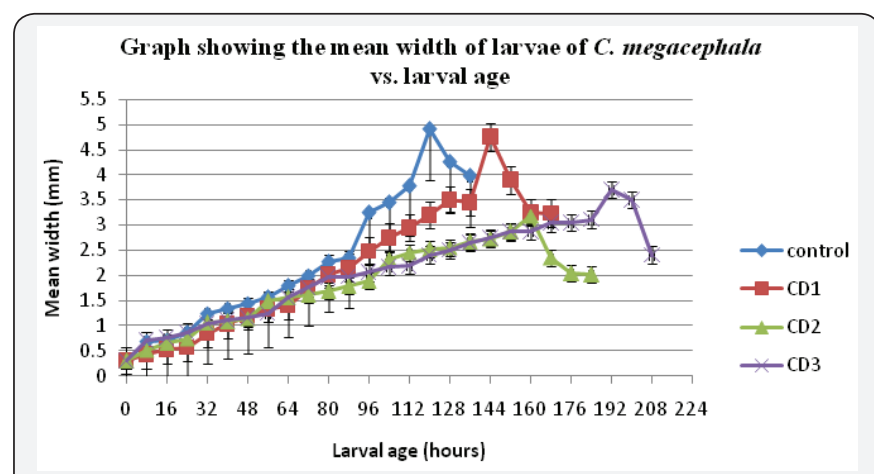

Figure 3: Showing the mean width of immature stages of C. megacephala exposed to different cadmium chloride concentrations.

Larval width has recently been regarded as a valuable parameter for age determination of larvae and consequently PMI estimation. The width of the larvae, viewed laterally, was measured between the ventral and dorsal surfaces at the junction of the fifth and sixth abdominal segment. [30]. the development curves created from the width data are (Figure 3). There are significant differences in widths of the larvae feeding upon the different doses of cadmium chloride and the time required to reach the maximum width $(F=263.864 ; p=0.001)$. Larvae belonging to the group CD1 attained maximum width at 144 hours ( $4.75 \pm 0.34 \mathrm{~mm}), \mathrm{CD} 2$ at 160 hours $(3.18 \pm 0.14 \mathrm{~mm})$ and CD3 at 184 hours $(3.11 \pm 0.24 \mathrm{~mm})$ respectively. The control group took less time to attain maximum width i.e. 120 hours $(4.9$ $\pm 0.27 \mathrm{~mm}$ ) as compared to treated groups [60]. Suggested that the differences in cadmium and mercury concentrations between sexes in mayflies may have resulted from different factors, including differences in body size and body composition [22]. Studied the effect of cadmium on the growth of Boettcherisca peregrina and evaluated the larval length. The larval body lengths were significantly shorter in comparison to control.

\section{Larval and pupal weight}

The mean larval weight varied significantly as the concentration of cadmium was increased (Table 1). The maximum weight of CD1 (99.97 $\pm 0.26 \mathrm{mg})$ was attained in 114 hours, while the maximum weight for the larvae feeding upon CD2 $(95.89 \pm 0.074 \mathrm{mg})$ and CD3 $(93.8 \pm 0.31 \mathrm{mg})$ was recorded at 160 and 184 hours respectively. Maximum weight of control group was $102.6 \pm 0.014 \mathrm{mg}$ attained at 120 hours. Pupal and adult weight was also decreased with increased concentration (Table 1) [61]. Reported that there were no significant differences between the adult weight of control and cadmium treated groups [3] studied that cadmium was the reason for the loss of weight of adult of Aiolopus thalassinus [22]. Studied the effect of cadmium on Chrysomya albiceps and concluded that cadmium caused decrease in pupal and adult body weight. The results from the present study also demonstrate that increase in the concentration of cadmium affects the larval and pupal weight negatively.

Table 1: Maximum weight of larvae, pupae and adults exposed to the different concentrations of cadmium chloride.

\begin{tabular}{|c|c|c|c|}
\hline $\begin{array}{c}\text { Different } \\
\text { concentration } \\
\text { of cadmium } \\
\text { chloride (mg/ } \\
\text { kgbw) }\end{array}$ & $\begin{array}{c}\text { Maximum } \\
\text { weight of } \\
\text { larva }\end{array}$ & $\begin{array}{c}\text { Maximum } \\
\text { weight of } \\
\text { pupa } \\
\text { (Mean } \pm \text { SD) } \\
\text { mg }\end{array}$ & $\begin{array}{c}\text { Maximum } \\
\text { weight of } \\
\text { Adult } \\
\text { (Mean } \pm \text { SD) } \\
\text { mg }\end{array}$ \\
\hline Control & $102.6 \pm 0.014$ & $99.56 \pm 1.27$ & $74.56 \pm 0.07$ \\
\hline CD1 & $99.96 \pm 0.26$ & $95.05 \pm 0.41$ & $70.67 \pm 0.11$ \\
\hline CD2 & $95.89 \pm 0.07$ & $92.8 \pm 0.25$ & $65.02 \pm 0.51$ \\
\hline CD3 & $93.8 \pm 0.31$ & $89.85 \pm 0.32$ & $57.34 \pm 0.47$ \\
\hline Analysis of & $\mathrm{F}=1,539.75$ & $\mathrm{~F}=346.79$ & $\mathrm{~F}=1,688.21$ \\
variance & $\mathrm{df}=3$ & $\mathrm{df}=3$ & $\mathrm{df}=3$ \\
$(\mathrm{p}<0.001)$ & $(\mathrm{p}<0.01)$ & $(\mathrm{p}<0.01)$ \\
\hline
\end{tabular}

\section{Larval mortality}

Table 2: Showing the percentage of larval and pupal mortality in C. megacephala exposed to different Concentration of cadmium chloride.

\begin{tabular}{|c|c|c|}
\hline $\begin{array}{c}\text { Different concentration } \\
\text { of cadmium chloride } \\
\text { (mg/kgbw) }\end{array}$ & $\begin{array}{c}\text { Larval mortality } \\
\text { (\%) }\end{array}$ & $\begin{array}{c}\text { Pupal mortality } \\
\text { (\%) }\end{array}$ \\
\hline Control & 3.16 & 4.67 \\
\hline CD1 & 5.96 & 9.95 \\
\hline CD2 & 11.05 & 14.50 \\
\hline CD3 & 19.68 & 21.19 \\
\hline
\end{tabular}

The larval stage showed more mortality due to cadmium than the pupal stage. The percentage of mortality was increased with the increase of cadmium chloride concentration (Table 2). In the control group there were no significant differences $(\mathrm{X} 2=$ $[\mathrm{p}=0.05, \mathrm{df}=1$, ] $=3.84$ ), but with increase in the concentration of cadmium, larval and pupal mortality was increased i.e. CD1 $(\mathrm{X} 2=[\mathrm{p}=0.01, \mathrm{df}=3]=11.34),, \mathrm{CD} 2(\mathrm{X} 2=[\mathrm{p}=0.01, \mathrm{df}=9]=$, 21.7 ) and CD3 (X2 = $[\mathrm{p}=0.01, \mathrm{df}=13]=27.7$,$) . The effect of$ cadmium chloride on mortality rate observed in the present study is similar to the previous studies [62]. Studied the effect of cadmium on the alligatorweed flea beetle Agasides hygrophila. The mortality rates were increased with presence of cadmium $[3,18]$. Observed a significantly short life span due the effect of cadmium in Aiolopus thalassinus. The nymphs were more tolerant than eggs and adults to different concentrations of cadmium [63] also reported that the longevity of Ceratitis capitata and Coptera occidentalis was negatively affected by cadmium. 


\section{Conclusion}

It can be concluded from this study that cadmium chloride has negative effect on every stage of the life cycle of Chrysomya megacephala. Larval development took longer time in the presences of high cadmium concentrations as compared to control. Larval, pupal and adult weights were decreased with its higher doses. Similarly there was greater mortality among the larvae and pupae under the influence of cadmium chloride. The time of death on the basis of insect evidence is generally determined by estimating the age of the maggots from a dead body. Since cadmium chloride alters the rate of development in Chrysomya megacephala. There are chances of miscalculation of PMI if the presence of cadmium chloride is not taken into consideration. For example there could be wrong estimation of PMI by up to 18-86 hours if age of larvae is determined on the basis of its length ignoring the effect of cadmium chloride. Hence the investigator must take into consideration the presence of chemical in the larval food that may affect the rate of development.

\section{References}

1. Van Straalen NM, Schobben JHM, De Goede RGM (1989) Population consequences of cadmium toxicity in soil microarthropods. Ecotoxico Environ Saf 17(2): 190-204.

2. Posthuma L (1990) Genetic differentiation between populations of Orchesella cincta (Collembola) from heavy metal contaminated site. J Appl Eco 27(2): 609-622.

3. Schmidt GH, Ibrahim NMM, Abdullah MD (1992) Long-term effects of heavy metals in food on developmental stages of Aiolopus thalassinus (Saltatoria: Acrididae). Arch Environ Contam Toxicol 23(3): 375-382.

4. Gintenreiter S, Ortel J, Nopp HJ (1993) Effects of different dietary levels of cadmium, lead, copper, and zinc on the vitality of the forest pest insect Lymantria dispar L (Lymantriidae, Lepidoptera). Arch Environ Contam Toxicol 25(1): 62-66.

5. Rayms Keller A, Oson KE, McGaw M, Oray C, Carison JO, et al. (1989) The effect of heavy metals on the Ades aegypti (Diptera : Culicidae) larvae. Ecotoxico Environ Saf 39(1): 41- 47.

6. Sildanchandra W, Crane M (2000) Influence of sexual dimorphism in Chironomus riparius Meigen on toxic effects of cadmium. Environ Toxicol Chem 19(9): 2309-2313.

7. Niu CY, Jiang Y, Lei CL, Hu C (2002) Effects of cadmium on housefly: influence on growth and development and metabolism during metamorphosis of housefly. Entomologia Sinica 9(1): 27-33.

8. Cervera A, Maymó A C, Sendra M, Martínez-Pardo R, Garcerá MD (2004) Cadmium effects on development and reproduction of Oncopeltus fasciatus (Heteroptera: Lygaeidae). J Insect Physiol 50(8): 737-749.

9. Ortel J, Vogel WR (1989) Effect of lead and cadmium on oxygen consumption and life expectancy of the pupal parasitoid, Pimpla turionella. Entomologia Experimentalis et Applicata 52: 83-88.

10. Islam A, Roy S (1983) Effects of $\mathrm{CdCl}_{2}$ on the quantitative variations of carbohydrate, protein, amino acid and cholesterol in Chrysochoris stolli Wolf (Insecta: Hemiptera). Curr Sci 52: 215-217.

11. Bischof C (1995) Effects of heavy metal stress on carbohydrate and lipid concentrations in the haemolymph and total body tissue of parasitized Lymantria dispar L. larvae (Lymantriidae). Comp Biochem Physiol 112: 87-92.

12. Ortel, J (1991) Effect of lead and cadmium on chemical composition and total water content of the pupal parasitoid, Pimpla turionellae Entomologia. Experimentalis. et. Applicata 59(1): 93-100.

13. Ortel J (1995) Effects of metals on the total lipid content in the gypsy moth (Lymantria dispar, Lymantriidae, Lepidoptera) and its hemolymph. Bull Enviro Contam Toxicol 55: 216-221.

14. Ortel J (1995) Metal-supplemented diets alter carbohydrate levels in tissue and hemolymph of gypsy moth larvae (Lymantria dispar, Lymantriidae, Lepidoptera). Ecotoxico Environ Saf 15(7): 1171-1176.

15. Shiao SF, Yeh TC (2008) Larval competition of Chrysomya megacephala and Chrysomya rufifacies (Diptera: Calliphoridae): Behaviour and ecological studies of two blow fly species of forensic significance. J Med. Ent 45(4): 785-799.

16. Nascarella MA, Jr Stoffolano JG, Stanek III EJ, Kostecki PT, Calabrese EJ (2003) Hormesis and stage specific toxicity induced by cadmium in an insect model, the queen blowfly, Phormia regina Meig Environ Poll 124: $257-262$.

17. Williams KA, Green DW J, Pascoe D, Gower DE (1987) Effect of cadmium on ovipiostion and egg viability in Chironomus riparius (Dipters: Chironomidae). Bull Enviro Contam Toxicol 38(1): 86-90.

18. Schmidt GH, Ibrahim NMM, Abdallah MD (1991) Toxicological studies on the long-term effects of heavy metals $(\mathrm{Hg}, \mathrm{Cd}, \mathrm{Pb})$ in soil on the development of Aiolopus thalassinus (Fabr) (Saltatoria: Acrididae). Scio Total Environ 107: 109-134.

19. Postma JF, Davids C (1995) Tolerance induction and life cycle changes in cadmium exposed Chironomus riparius (Diptera) during consecutive generations. Ecotoxico Environ Saf 30(2): 195- 202.

20. Postma JF, Buckert de Jong MC, Staats N, Davids C (1994) Chronic toxicity of cadmium to Chironomus riparius (Diptera: Chironomidae) at different food levels. Arch Environ Contam Toxicol 26(2): 143-148.

21. ALMisned FAM (2001) Biological effects of cadmium on life cycle parameters of Chrysomya albiceps (Wiedemann) (Diptera:calliphoridae). Kuwait J Sci Eng 28: 179-188.

22. Wu GX, Ye GY, Hu C, Cheng JA (2006) Accumulation of cadmium and its effects on growth, development and haemolymph biochemical compositions in Boettcherisca peregrina larvae (Diptera: Sarcophagidae). Insect Sci 13(1): 31-39.

23. Mircic D, Jankovic tomanic M, Nenadovic V, Franeta, F, Lazarevic J (2010) The effect of cadmium on the life history traits of Lymantria dispar Lepidoptera. Arch Bio Sci 62(4): 1013-1020.

24. Bharti M, Singh D, Sharma YP (2007) Effect of temperature on thedevelopment of forensically important blowfly, Chrysomya megacephala (Fab.) (Diptera: Calliphoridae). Entomon 32(2): 149-151.

25. Tarone AM, Picard CJ, Spiegelman C, Foran DR (2011) Population and Temperature Effects on Lucilia sericata (Diptera: Calliphoridae) Body Size and Minimum Development Time. J Med Entomol 48(5): 10621068.

26. Warren JA, Anderson GS (2013) Effect of fluctuating temperatures on the development of a forensically important blow fly, Protophormia terraenovae (Diptera: Calliphoridae). Environ Entomol 42(1): 167172.

27. Alonso MA, Souza CM, Linhares AX, Thyssen, PJ (2015) Egg Developmental Time and Survival of Chrysomya megacephala and Chrysomya putoria (Diptera: Calliphoridae) under different temperatures. J Med Entomol 52(4): 551-556.

28. Kaneshrajah G, Turner B (2004) Calliphora vicina larvae grow at different rates on different body tissues. Int J Legal Med 118(4): 242244.

29. Clark K, Evans L, Wall R (2006) Growth rates of the blowfly, Lucilia sericata, on different body tissues. Forensic Sci Int 156(2-3): 145-149. 
30. Day MD, Wallman JF (2006a) Influence of substrate tissue type on larval growth in Calliphora augur and Lucilia cuprina (Diptera: Calliphoridae). J Forensic Sci 51(3): 657-663.

31. Ireland S, Turner B (2006) The effects of larval crowding and food type on the size and development of the blowfly, Calliphora vomitoria. Forensic Sci Int 159(2-3): 175-181.

32. Ujvari B, Wallman JF, Madsen T, Whelan M, Hulbert A (2009) Experimental studies of blowfly (Calliphora stygia) longevity: a little dietary fat is beneficial but too much is detrimental. Comp Biochem Physiol A Mol Integr Physiol 151(4): 383-388.

33. Oliveira HG, Gomes G, Morlin JJ, Von Zuben CJ, Linhares AX (2009) The effect of Buscopan on the development of the blow fly Chrysomya megacephala (F.) (Diptera: Calliphoridae). J Forensic Sci 54(1): 202206.

34. Arong GA, Imandeh GN, Utsu AA, Shaa KK (2011) The influence of food type on larval growth in Musca domestica and Lucilia sericata (Diptera) in Calabar, Nigeria. World J Sci Technol 1: 73-77.

35. Rabelo KC, Thyssen PJ, Salgado RL, Araujo MS, Vasconcelos SD (2011) Bionomics of two forensically important blowfly species Chrysomya megacephala and Chrysomya putoria (Diptera: Calliphoridae) reared on four types of diet. Forensic Sci Int 210(1-3): 257-262.

36. Li X, Yang Y, Li G, Li H, Wang Q, Wan L ( 2014) The effect of dietary fat levels on the size and development of Chrysomya megacephala (Diptera: Calliphoridae). J Insect Sci.

37. Thyssen PJ, De Souza CM, Shimamoto PM, Salewski Tde B, Moretti TC (2014) Rates of development of immatures of three species of Chrysomya (Diptera: Calliphoridae) reared in different types of animal tissues: implications for estimating the postmortem interval. Parasitol Res. 113(9): 3373-3380.

38. Carvalho LML, Linhares AX, Trigo JR (2001) Determination of drug levels and the effect of diazepam on the growth of necrophagous flies of forensic importance in southeastern Brazil. Forensic Sci Int 120(12): $140-144$.

39. Musvasa E, Williams KA, Muller W J, Villet MH (2001) Preliminary observations on the effects of hydrocortisone and sodium methohexital on development of Sarcophaga (Curranea) tibialis Macquart (Diptera: Sarcophagidae), and its implications for estimating post mortem interval. Forensic Sci Int 120(1-2): 37-41.

40. Pien K, Laloup M, Pipeleers-Marichal M, Grootaert P, Boeck GD, et al. (2004) Toxicological data and growth characteristics of single postfeeding larvae and puparia of Calliphora vicina (Diptera: Calliphoridae) obtained from a controlled nordiazepam study. Int J Legal Med 118 (4): 190-193.

41. Tabor KL, Fell RD, Brewster CC, Pelzer K, Behonick GS (2005) Effects of antemortem ingestion of ethanol on insect successional patterns and development of Phormia regina (Diptera: Calliphoridae). J Med Ent 42(3): 481-489.

42. Gola S, Lukose S (2007) A study of presence of ante-mortem administered drugs and to analyse them in the different stages of insect development. Int J Med Tox Legal Med 10(1): 12-15.

43. Rashid RA, Osman K, Ismail MI, Zuha RM, Hassan RA (2008) Determination of malathion levels and the effect of malathion on the growth of Chrysomya megacephala (Fabricius) in malathion-exposed rat carcass. Trop Biomed 25(3): 184-190.

44. Gosselin M, Fazio V, Wile MR, Samyn N, Bourel B, et al. (2011) Methadone determination in puparia and its effect on the development of Lucilia sericata (Diptera, Calliphoridae). Forensic Sci Int 209(1-3): 154-159.

45. Carvalho LML, Linhares AX, Palhares FAB (2012) The effect of cocaine on the development rate of immatures and adults of Chrysomya albiceps and Chrysomya putoria (Diptera: Calliphoridae) and its importance to postmortem interval estimate. Forensic Sci Int 220(13): $27-32$.

46. Zou Y, Huang M, Huang R, Wu X, You Z, et al. (2013) Effect of ketamine on the development of Lucilia sericata (Meigen) (Diptera: Calliphoridae) and preliminary pathological observation of larvae. Forensic Sci Int 226(1-3): 273-281.

47. Lü Z, Zhai X, Zhou H, Li P, Ma J, et al. (2014) Effects of Ketamine on the Development of forensically important Blowfly Chrysomya megacephala (F.) (Diptera: Calliphoridae) and its Forensic Relevance. J Forensic Sci 59(4): 991-996.

48. Singh D, Heer BK, Wadhawan B (2014) Effect of Ketamine hydrochloride in Combination with Xylazine on the development of Chrysomya megacephala Fab. Ind J Forensic Med Toxicol 8(1): 139-145.

49. Rezende F, Alonso MA, Souza CM, Patrícia J, Thyssen PJ, et al. (2014) Developmental rates of immature of three Chrysomya species (Diptera: Calliphoridae) under the effect of methylphenidate hydrochloride, phenobarbital, and methylphenidate hydrochloride associated with Phenobarbital. Parasitol Res 113(5): 1897-1907.

50. Singh D, Bharti M (2000) Forensically important blow flies (Diptera: Calliphoridae) of Punjab (India). Uttar Pradesh J Zool 20(3): 249-251.

51. Bharti M, Singh D (2003) Insect faunal succession on decaying rabbit carcasses in Punjab, India. J Forensic Sci 48(5): 1133-1143.

52. Bharti M, Singh D (2006) Occurrence of different larval stages of blowflies (Diptera: Calliphoridae) on decaying rabbit carcasses. Journal of Entomological Research 26(4): 343-350.

53. Smith KGV (1986) A Manual of Forensic Entomology, London: British Museum (Natural History), 205pp.

54. Goff ML, Flynn MM (1991) Determination of postmortem interval by arthropod succession: a case study from the Hawaiian Island. J Forensic Sci 36(2): 607-614.

55. Greenberg B (1991) Flies as forensic indicators. J Med Ento 28(5): 565577.

56. Sukontason KL, Narongchai P, Sripakdee D, Boonchu N, Chaiwong T, et al. (2005) Forensically-important fly maggots in a floating corpse: The first case report in Thailand. J Med Assoc Thai 88(10): 1458-1461.

57. Wang J, Hu C, Chen Y, Min J, Li J (2002) Effect of temperature over the body-length change of Chrysomya megacephala (Fabricius). Acta Parasitol Med Entomol Sinica 9: 100-105.

58. Duke LD (2004) Method Validation for Amitriptyline and Nortriptyline in Artificial Foodstuff. CPRC Ottawa 1-183.

59. Pascoe D, Williams KA, Green DJG (1989) chronic toxicity of cadmium to Chironomus riparius Meigen: effects upon larval development and adult emergence. Hydrobiologia 175(2): 109-115.

60. Dukerschein JT, Wiener JG, Rada RG, Steingraeber MT (1992) Cadmium and mercury in emergent mayflies (Hexagenia bilineata) from the Upper Mississippi River. Arch Environ Contam Toxicol 23(1): 109-116.

61.Cheng, L (1980) Incorporation of cadmium into Drosophila. Environmental pollution series A; Ecological and Biological. 21: 85-88.

62. Quimby PC, Frick KE, Wauchope PD, Key SH (1979) Effect of cadmium on two biocontrol insect and their host weeds. Bull Enviro Contam Toxicol 22(1): 41-47.

63. Kazimirova M, Slovak M, Monova A (1997) Host- parasitoid relationship of Ceratitis capitata (Diptera: Tephritidae) and Coptera occidentalis (Hymenoptera: Procototrupoida : Diapriidae) under host heavy metal stress. Euro J Ento 94 (3): 409- 420.

64. Radhakrishnaiha K, Busappa B (1986) Effect of cadmium on the 
carbohydrate metabolism of the freshwater field crab, Oziotelphusa senex senex (Fabrizius). J Environ Bio 7: 17-21.
65. Shin BS, Choi RN, Lee CU (2001) Effects of cadmium on total lipid content and fatty acids of the greater wax moth, Galleria mellonella. Kor J Eco 24: 349- 352

This work is licensed under Creative Commons Attribution 4.0 License

DOI: $10.19080 /$ JFSCI.2017.03.555622

\section{Your next submission with Juniper Publishers will reach you the below assets}

- Quality Editorial service

- Swift Peer Review

- Reprints availability

- E-prints Service

- Manuscript Podcast for convenient understanding

- Global attainment for your research

- Manuscript accessibility in different formats

( Pdf, E-pub, Full Text, Audio)

- Unceasing customer service

Track the below URL for one-step submission https://juniperpublishers.com/online-submission. 